\title{
Interaction of Angiotensin Peptides and Zinc Metal Ions Probed by Electrospray Ionization Mass Spectrometry
}

\author{
Joseph A. Loo and Peifeng Hu \\ Parke-Davis Pharmaceutical Research, Division of Warner-Lambert Company, 2800 Plymouth Road, Ann \\ Arbor, Michigan, USA
}

\author{
Richard D. Smith \\ Chemical Sciences Department. Pacific Northwest Laboratory, Richland, Washington, USA
}

\begin{abstract}
Electrospray ionization-tandem mass spectrometry experiments were used to provide evidence regarding the sites of interactions between zinc metal ions and angiotensin peptides. The electrospray ionization mass spectra of histidine-containing human angiotensin II (AspArg-Val-Tyr-Ile-His-Pro-Phe) and angiotensin I (Asp-Arg-Val-Tyr-Ile-His-Pro-Phe-His-Leu) in the presence of zinc show abundant multiply charged ions for the zinc-attached peptide $\left[\mathrm{M}+a \mathrm{Zn}^{2+}+(c-2 a) \mathrm{H}^{+}\right]^{\mathrm{c}+}$, where $a=1,2$ and $c$ is charge. From collisionally activated dissociation experiments, with both low energy (triple quadrupole mass spectrometry) and high energy collisions (linked scan at constant $B / E$ with a double focusing instrument) of the $[\mathrm{M}+\mathrm{Zn}]^{2+}$ and $[\mathrm{M}+\mathrm{Zn}+\mathrm{H}]^{3+}$ ions for angiotensin II, a $\left[b_{6}+\mathrm{Zn}\right]^{2+}$ species is produced as the most abundant product ion, suggesting that the zinc interaction site is in the vicinity of the $\mathrm{His}^{6}$ residue. Additionally, tandem mass spectra from the zinc-attached ions for angiotensin I show abundant $\left[b_{6}+\mathrm{Zn}\right]^{2+}$ and $\left[b_{9}+\mathrm{Zn}\right]^{2+}$ products, providing evidence that both $\mathrm{His}^{6}$ and $\mathrm{His}^{9}$ are involved in zinc coordination. (I Am Soc Mass Spectrom 1994, 5, 959-965)
\end{abstract}

$\mathrm{M}$ etal ion binding is an important facet of the function of many protein systems. Metal ions are an integral component of many enzymes (metalloenzymes) and are essential to their catalytic function and structural stability [1]. Well established techniques used to study the interaction between metal ions and biological materials include absorption spectroscopy, circular dichroism [2], electron paramagnetic resonance spectroscopy [3], nuclear magnetic resonance (NMR) spectroscopy [3, 4], extended $x$-ray absorption fine structure [5-7], and $x$-ray crystallography $[8,9]$. A rapidly growing method for investigating interactions between metal ions and biomolecules is mass spectrometry.

Many metal binding studies have been reported that involve fast-atom bombardment produced singly charged metal-peptide complexes and tandem mass spectrometry. Information about the intrinsic interactions of the metal and the peptide have heen extracted from the dissociation chemistry, based on the assumption that the charge on the metal ion induces binding site-specific fragmentation, and that the high vacuum of a mass spectrometer provides an ideal environment

Address reprint requests to Dr. Joseph A. Loo, Parke-Davis Pharmaceutical Research, 2800 Plymouth Road, Aru Arbor, MI 48105. to observe intrinsic interactions between peptides and metal ions due to the absence of solvation effects. Metal ion-peptide interactions that have been studied include those that involve alkali [10-17], alkaline earth [18-21], and transition metal ions [21, 22].

Electrospray ionization (ESI) [23, 24], which analyzes materials from solution, is generating increasing interest as a bioanalytical method because it has the ability to ionize efficiently large molecular weight biomolecules and has the potential to provide primary structure information by tandem mass spectrometry [25]. The potential of electrospray ionization-mass spectrometry (ESI-MS) to determine peptide-metal ion stoichiometry in a rapid and sensitive fashion is promising. Hutchens and co-workers [26, 27] have investigated interactions of $\mathrm{Cu}^{2+}$ and $\mathrm{Zn}^{2+}$ to cysteine (sulfur) [26, 27] and histidine [28] containing polypeptides with ESI. Their ESI-MS results suggest that ESI mass spectra reflect the specific association of the metal(s) to the peptide and can clearly be differentiated from nonspecific interactions due to clustering or adduct formation. Fenselau and co-workers [29] developed an ESI-MS strategy that provides analysis of metal ions in native and reconstituted metallothionein proteins. Seven divalent $\mathrm{Zn}^{2+}$ or $\mathrm{Cd}^{2+}$ metal ions were observed to associate with the fully reconstituted pro- 
tein. This observation agrees well with the results of solution studies, and it was therefore suggested that metalluthionein proteins retain their conformation in the gas phase.

Functionalized side chains of amino acids often define the characteristics of peptide interactions with metal ions. The imidazole side chain of a histidyl residue, in particular, is an excellent electron donor and serves as a metal binding site in a variety of enzymes [1]. Histidine-metal binding also has been reported for gas-phase metal-peptide complexes [10, $11,14]$. The imidazole group involved was either neutral [30] or deprotonated [21], whereas the peptides were all deprotonated species. In solution, the imidazole side chain of a histidine residue is a good anchor for transition metal ions to resist metal hydrolysis and induce deprotonation at peptide bonds at high $\mathrm{pH}$ [31].

In this mass spectrometry study, we target complexes in which a neutral peptide and $\mathrm{Zn}^{2+}$ are involved. Among the first row transition metal ions, $\mathrm{Zn}^{2+}$ is the second most abundant and important in biological systems [32]. Nearly 300 enzymes in different species of all phyla have zinc as an indispensable component for their functions [33, 34]. We show the impact of histidyl residue(s) on the fragmentation of $\mathrm{Zn}^{2+}$-angiotensin peptide complexes and discuss the implications to the metal binding site(s) in the peptide.

\section{Experimental}

\section{Electrospray Ionization Mass Spectrometer}

Two different instruments and experimental systems were utilized for this study. The triple quadrupole mass spectrometer (Sciex TAGA 6000E, Thornhill, Ontario, Canada; $m / z$ limit 1400) utilizes a modified atmospheric pressure inlet that incorporates a differentially pumped nozzle-skimmer interface [35]. A countercurrent stream of nitrogen was used to aid droplet desolvation. In addition, control of the voltage difference between the nozzle and skimmer elements ( $\Delta V_{\mathrm{NS}}$ ) is used to adjust the amount of collisional activation the molecules undergo in this region for desolvation and at higher levels of $\Delta V_{\mathrm{NS}}$, dissociation of the molecule. The ESI source, which utilizes a liquid sheath electrode, has been previously described [35]. Methanol or distilled deionized water were used as the sheath liquid, with the applied electrospray voltage at $+4 \mathrm{kV}$ and $+5.5 \mathrm{kV}$, respectively. Sulfur hexafluoride $\left(\mathrm{SF}_{6}, 99.8 \%\right.$ minimum purity) was used as a sheath gas and is an effective electron scavenger to suppress corona discharge [36], especially at the higher ESI voltages necessary for spraying completely aqueous solutions. A syringe pump (Harvard Apparatus, South Natick, MA) controlled the analyte delivery rate to the ESI source at $0.35 \mu \mathrm{L} \mathrm{min}{ }^{-1}$. A separate syringe pump delivered the sheath liquid flow at a rate of $3 \mu \mathrm{L}$ $\min ^{-1}$. Argon was used as the collision gas for the triple quadrupole-tandem mass spectrometry experiments.

ESI-MS analyses also were performed with a Finnigan MAT 900 (Bremen, Germany) forward geometry double focusing mass spectrometer [37] equipped with a $20-\mathrm{kV}$ conversion dynode-electron multiplier point detector and a position and time-resolved ion counting array detector (PATRIC). The scanning PATRIC-array detector was used for acquisition of most of the data from this instrument. Analyses were performed at full accelerating potential $(5 \mathrm{kV})$, except for linked scan at constant $B$ /E experiments of multiply charged precursor ions. Sample solutions were infused through the ESI source at a flow rate of $0.5-1.5 \mu \mathrm{L} \mathrm{min}{ }^{-1}$. Mass spectra were typically acquired at $30 \mathrm{~s}$ decade ${ }^{1}$.

The electrospray ionization interface on the double focusing instrument is based on a heated glass capillary inlet [23] $(0.5 \mathrm{~mm}$ i.d. $\times 6.2 \mathrm{~mm}$ o.d. $\times 218 \mathrm{~mm}$ length). In a fashion similar to the ESI-quadrupole mass spectrometer interface, droplet desolvation is accomplished by a countercurrent stream of warm nitrogen $\left(\sim 60^{\circ} \mathrm{C}\right)$ and by energetic collisions in the electrospray interface. The energy of the collisions is controlled by the voltage difference between the tube lens surrounding the metalized exit of the glass capillary and the first skimmer element of the interface $\left(\Delta V_{\mathrm{TS}}\right)$. The typical range of $\Delta V_{\mathrm{Ts}}$ used for this work was $+90-120 \mathrm{~V}$. Sulfur hexafluoride coaxial to the spray was also used to suppress corona discharges.

For linked scan at constant $B / E$ experiments, helium gas sufficient to reduce the precursor ion abundance to $50 \%$ was introduced into the collision chamber in the first field-free region. The array detector was used for the constant $B / E$ experiments. Due to the use of an array detector on a double focusing instrument, any precursor ion selectivity of the $\mathrm{B} / \mathrm{E}$ linked scan was lost. The precursor ion beam is actually a sum of ions whose masses fall into the $2 \%$ window of the intended precursor mass. (In practice, the mass-tocharge ratio range that is passed tends to be larger than $2 \%$ of the precursor ion mass-to-charge ratio; however, the transmission for ions outside the window declines exponentially,) All product ions from all ions within the precursor ion window also were recorded. This inherent lack of precursor ion selectivity sometimes causes artifacts in the tandem mass spectrum if there are any other potential precursor ions (including precursors that contain heavy isotopes) whose masses fall in this mass window. Because of the relatively low resolution in precursor selectivity, the entire isotopic distribution of the precursor ion is passed (as opposed to only the ${ }^{12} \mathrm{C}$ isotope ion) and is reflected in the product ion isotopic distribution pattern. Product ion resolution is generally greater than 1000 .

\section{Materials}

Angiotensin I, angiotensin II, N-acetyl-renin substrate tetradecapeptide, and substance $P$ were purchased 
from Sigma Chemical (St. Louis, MO) and were used without further purification. Peptide AAAYAA was purchased from Bachem Bioscience (Philadelphia, PA). Peptides with the sequence DRVYIAPF ([Ala $\left.{ }^{6}\right]$-angiotensin II) and DRVYTHAF ([Ala ${ }^{7}$-angiotensin II) were provided by Dr. Wayne Cody (Parke-Davis Pharmaceutical Research, Ann Arbor, MI). For the triple quadrupole mass spectrometry studies, peptide solutions, at concentrations approximately $100 \mathrm{pmol} \mu \mathrm{L}^{-1}$, were prepared in distilled deionized water with either $5 \%$ glacial acetic acid $(\mathrm{v} / \mathrm{v})$ or no acetic acid added (see Results and Discussion). For experiments that used the double focusing mass spectrometer, samples were prepared at a concentration of $10-50 \mathrm{pmol}_{\mu \mathrm{L}^{-1}}$ in distilled water with acetic acid or ammonium hydroxide added to adjust the $\mathrm{pH}$.

\section{Results and Discussion}

\section{Gas-Phase $\mathrm{Zn}^{2+}$-Angiotensin Peptide Complexes}

The addition of 1-10-mM $\mathrm{ZnCl}_{2}$ to a $\mathrm{pH} 6,50-100$ pmol $\mu \mathrm{L}^{-1}$ aqueous solution of angiotensin II $\left(M_{\mathrm{r}}=\right.$ 1046, DRVYIHPF) yielded electrospray mass spectra that showed the incorporation of one $\mathrm{Zn}^{2+}$ ion bound to the peptide, with a much less abundant set of peaks that represented two zinc ions bound to the peptide (Figure 1a). Angiotensin I $\left(M_{r}=1296\right.$, DRVYIHPFHL) has histidine residues at positions 6 and 9. The ESI mass spectrum of human angiotensin $\mathbf{I}$ in the presence of $1-\mathrm{mM} \mathrm{ZnCl}{ }_{2}$ again shows the association of one zinc ion as the most abundant species (Figure 1b). From accurate mass measurements taken from higher resolution scanning experiments with the double focusing instrument ( $\sim 1$-ppm mass accuracy), the general formula that describes the stoichiometry of the complex is given by $\left[\mathrm{M}+a \mathrm{Zn}^{2+}+(c-2 a) \mathrm{H}^{+}\right]^{c+}$, where $c$ is charge. The relative abundance of the peptide-metal complex plateaus near $\mathrm{pH}^{-7}$ and falls off dramatically at $\mathrm{pH} 3$ and 10 .

The relative abundance of the metal-bound ions is dependent on charge state. As shown in Figure 1a and $\mathrm{b}$, the relative abundance of the $[\mathrm{M}+\mathrm{Zn}+\mathrm{C}-$ 2) $\mathrm{H}]^{c+}$ ions versus $[\mathrm{M}+c \mathrm{H}]^{c+}$ ions increases with increasing charge $c$. (The same trend is observed for the relative abundance of the $[\mathrm{M}+2 \mathrm{Zn}+(c-4) \mathrm{H}]^{c+}$ ions.) The isotopic abundance ratio of zinc for masses 64:66:67:68:70 is 100:57.4:8.4:38.7:1.3. This isotopic pattern is an unique fingerprint for any ionic species that incorporates zinc, as shown by the collisionally activated dissociation (CAD) data.

\section{Collisionally Activated Dissociation of $\mathrm{Zn}^{2+}-$ Angiotensin Peptide Complexes}

Comparison of the CAD mass spectra of the protonated and metal-bound peptides provides information regarding the nature of the metal-peptide interaction. CAD of the $[\mathrm{M}+2 \mathrm{H}]^{2+}$ molecule for angiotensin II
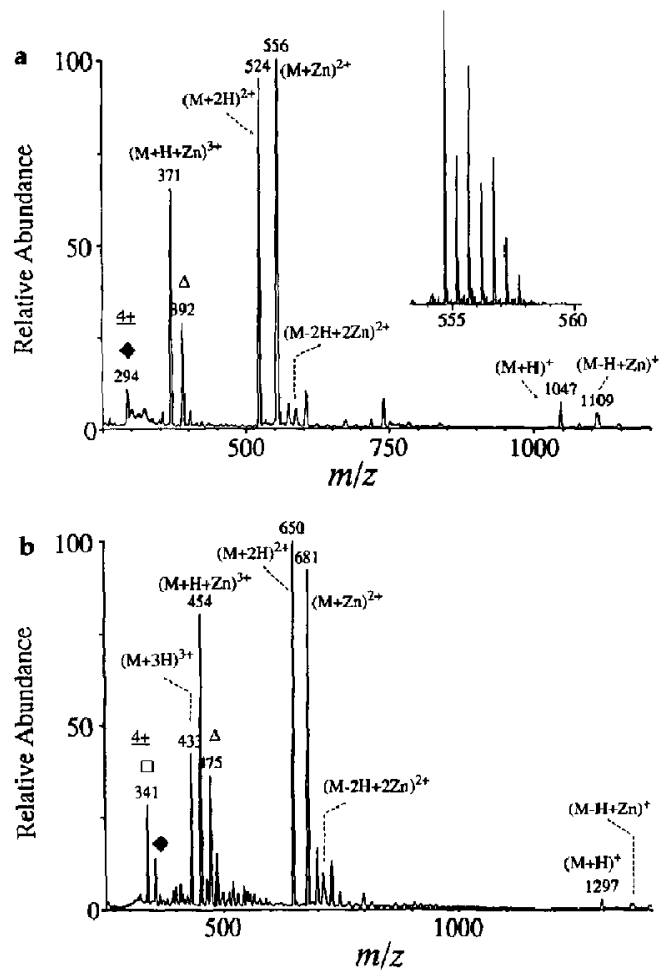

Figure 1. Electrospray ionization quadrupole mass spectra of (a) human angiotensin II and (b) angiotensin I in the presence of 1-mM $\mathrm{ZnCl}_{2}$. Symbols are used to label some of the peaks: $\Delta$, $[\mathrm{M}-\mathrm{H}+2 \mathrm{Zn}]^{3+} ; \mathrm{\square},[\mathrm{M}+2 \mathrm{H}+\mathrm{Zn}]^{4+} ;,[\mathrm{M}+2 \mathrm{Zn}]^{4+}$. The inset of (a) shows an expansion of the $[\mathrm{M}+\mathrm{Zn}]^{2+}$ region of the spectrum acquired with the double focusing instrument at a resolution of 8000 .

shows a series of $a_{n} / b_{n}$ singly charged product ions under both low energy collision conditions (triple quadrupole) and higher energy collisions (EB) (Figure $2 \mathrm{a}$ and $3 \mathrm{a}$, respectively). CAD of the $[\mathrm{M}+\mathrm{Zn}]^{2+}$ molecule, obtained with both instrumental systems, produces primarily the $\left[b_{6}+\mathrm{Zn}\right]^{2+} /\left[a_{6}+\mathrm{Zn}\right]^{2+}$ pair in addition to the ions formed by water loss (approximately $30 \%$ relative abundance; see Figures $2 \mathrm{~b}$ and $3 \mathrm{~b}$ ). [Nomenclature used for the oligopeptide fragmentation pattern is based on conventional notation [38]. A superscript is added to indicate the fragment ion charge state. For dissociation of the $\mathrm{Zn}$-peptide ion complex, $Z n$-attached product ions are explicitly labeled as the zinc-containing species (e.g., $\left[b_{6}+\mathrm{Zn}\right]^{2+}$ ). An ion not explicitly labeled with zinc (e.g., $b_{2}^{+}$) should be assumed to be not zinc bound.] This kind of spectral simplification that occurs upon metal ion complexation was pointed out by Gross and co-workers [14] for alkali metal ions. Dissociation of the $\mathrm{His}^{6}-\mathrm{Pro}^{7}$ bond is seemingly favored upon association with zinc.

Zinc binding has a similar influence on the CAD of angiotensin I. The CAD mass spectra of the doubly (Figure 4a) and triply (Figure 5a) protonated species 

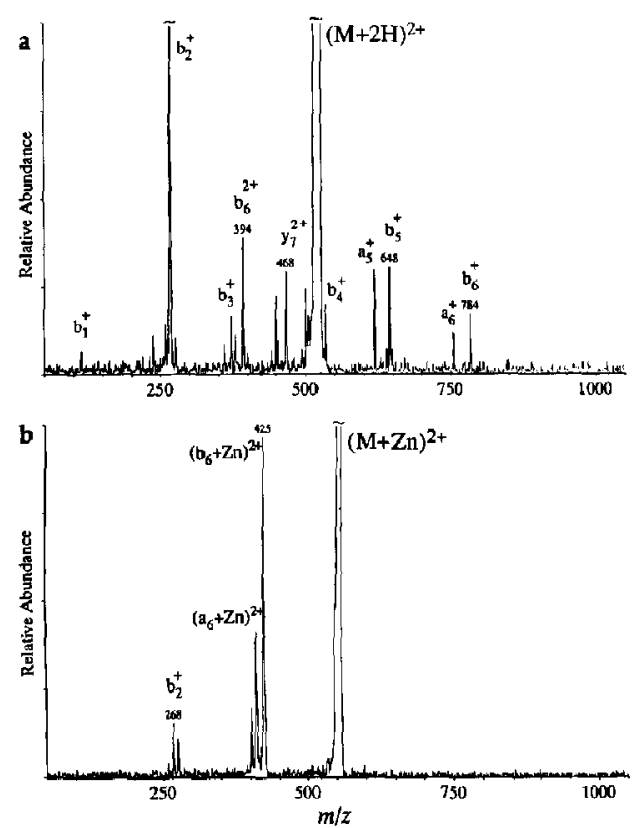

Figure 2. ESI-CAD mass spectra of the (a) $[\mathrm{M}+2 \mathrm{H}]^{2+}$ and (b) $[M+Z n]^{2+}$ molecules of angiotensin II, acquired with the triple quadrupole mass spectrometer (argon collision gas).
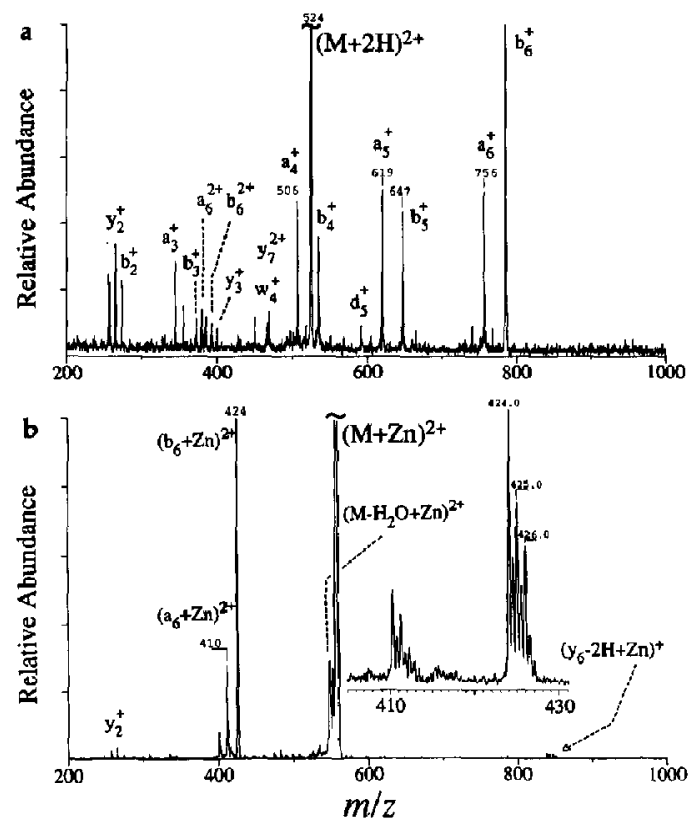

Figure 3. Linked scan at constant $\mathrm{B} / \mathrm{E}$ of the (a) $[\mathrm{M}+2 \mathrm{H}]^{2+}$ and (b) $[\mathrm{M}+\mathrm{Zn}]^{2+}$ molecules of angiotensin II (helium collision gas).
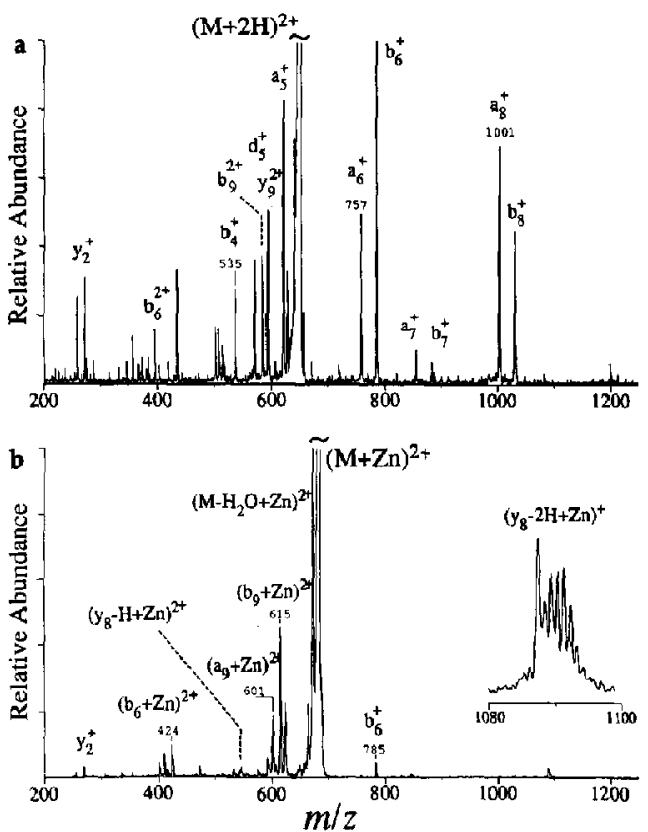

Figure 4. ESI-linked scan at constant $B / E$ of the (a) $[M+2 H]^{2+}$ and (b) $[M+Z n]^{2+}$ molecules of angiotensin $I_{r}$ acquired with the double focusing mass spectrometer (helium collision gas).
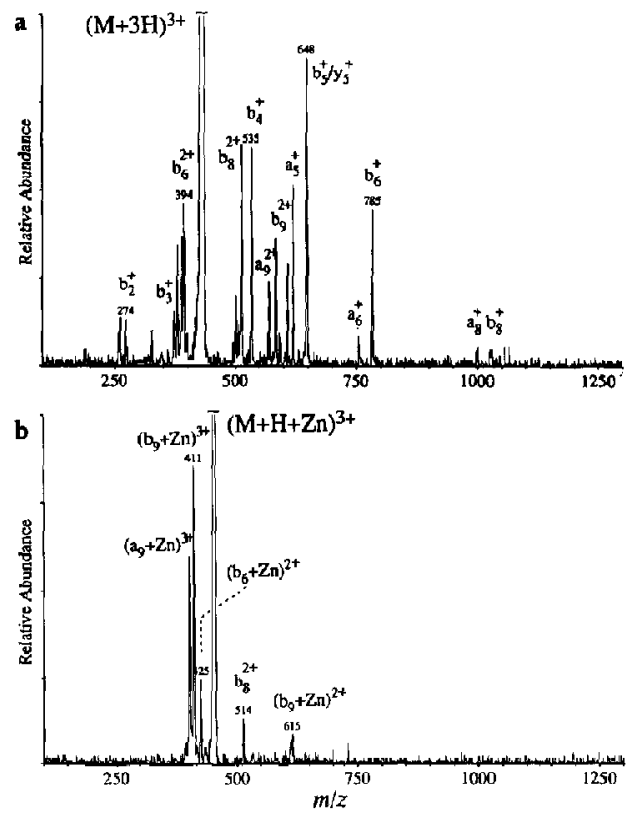

Figure 5. CAD spectra (triple quadrupole mass spectrometer) of the (a) $[\mathrm{M}+3 \mathrm{H}]^{3+}$ and (b) $[\mathrm{M}+\mathrm{H}+\mathrm{Zn}]^{3+}$ species of angiotensin I. 
from angiotensin I show singly and doubly charged fragments distributed across the entire backbone. CAD of the $[\mathrm{M}+\mathrm{Zn}]^{21}$ at $m / z 681$ yields an ion at $m / z$ 615 , which represents the zinc-attached $\left[b_{9}+\mathrm{Zn}\right]^{2+}$ species, as the most abundant product ion, with smaller contributions from $\left[b_{6}+Z n\right]^{2+}$ (Figure $4 b$ ). Dissociation of the $\mathrm{His}^{9}-\mathrm{Leu}^{10}$ amide bond is favored over dissociation of the $\mathrm{His}^{6}-\mathrm{Pro}^{7}$ bond for the zinc-angiotensin I complex (vide infra). The CAD spectrum for the $[\mathrm{M}+\mathrm{Zn}+\mathrm{H}]^{3+}$ parent ion (Figure $5 \mathrm{~b}$ ) also shows the $\left[b_{9}+Z n\right]^{2+} /\left[a_{9}+Z n\right]^{2+}$ pair as the dominant peaks with lower abundance peaks for $b_{8}^{2+}$ and $\left[b_{6}+\mathrm{Zn}\right]^{2+}$ also evident. Similar CAD data were obtained from goosefish angiotensin $I\left(M_{\mathrm{r}}=1282\right)$, where Asp ${ }^{1}$ and Ile $^{5}$ of human angiotensin I have been replaced with Asn and Val, respectively. An ion that corresponds to a zinc-containing $y_{8}$ product ion from dissociation of $\mathrm{Arg}^{2}-\mathrm{Val}^{3}$ also was observed (Figure 4b). A similar fragmentation product also was observed for the angiotensin II-zinc complex (i.e., $\left[y_{6}-\right.$ $2 \mathrm{H}+\mathrm{Zn}]^{+}$; Figure $3 \mathrm{~b}$ ).

\section{Zinc-Histidine Binding}

Metal cationization by $\mathrm{Zn}^{2+}$ was observed to dramatically reduce the number of $\mathrm{CAD}$ fragmentation channels for the angiotensin peptides (e.g., compare the fragmentation of $[\mathrm{M}+2 \mathrm{H}]^{2+}$ with that of $[\mathrm{M}+\mathrm{Zn}]^{2+}$ ). The major product ions (except water loss) are formed by reactions at the histidine sites ( $\mathrm{His}^{6}-$ Pro for angiotensin II; $\mathrm{His}^{6}$-Pro and His ${ }^{9}$ - Leu for angiotensin I). This histidine specificity may be the result of preferential binding of $\mathrm{Zn}^{2+}$ to the histidine residue and the charge on the metal ion induces fragmentation at that site. This is further supported by the experimental results with $\left[\mathrm{Ala}^{6}\right]$-angiotensin II and other non-histidine-containing peptides such as substance $P$. The $\mathrm{Ala}^{6}$-Pro bond is only one fragmentation site among others in the CAD spectrum of the ([Ala $\left.{ }^{6}\right]-$ angiotensin II $+\mathrm{Zn})^{2+}$ complex (Figure 6), and the ion due to water loss becomes the most abundant product ion. $\mathrm{CAD}$ of $\left(\left[\mathrm{Ala}^{6}\right] \text {-angiotensin II }+2 \mathrm{H}\right]^{2+}$, however, gives abundant $b_{6}^{+}$and $b_{6}^{2+}$ ions, in agreement with previous studies on the influences of proline over the fragmentation of protonated peptides [39]. Substance P (RPKPQQFFGLM-NH ${ }_{2}$ ) does not contain histidine as well. The major fragmentation channels for [substance $\mathrm{P}+\mathrm{Zn}]^{2+}$ are the same for [substance $\left.\mathrm{P}+2 \mathrm{H}\right]^{2+}$. The protonated species produces both singly and doubly charged $a_{7}, a_{9}, b_{9}, a_{10}$, and $b_{10}$ ions [40], whereas the $\mathrm{Zn}^{2+}$ complex produces $\mathrm{Zn}^{2+}$-attached product ions of the same type (e.g., $\left.\left[b_{10}+\mathrm{Zn}-\mathrm{H}\right]^{+}\right)$. Also, the fragmentation efficiency is reduced dramatically for the $\mathrm{Zn}^{2+}$ complex for non-histidine-containing peptides (see Figure 6). This lends further support to the notion that the facile fragmentation at the histidine sites is promoted by $\mathrm{Zn}^{2+}$ attachment to histidine residues.

Dissociation of the amide $x$-Pro bond has been observed to be a favored process for multiply charged
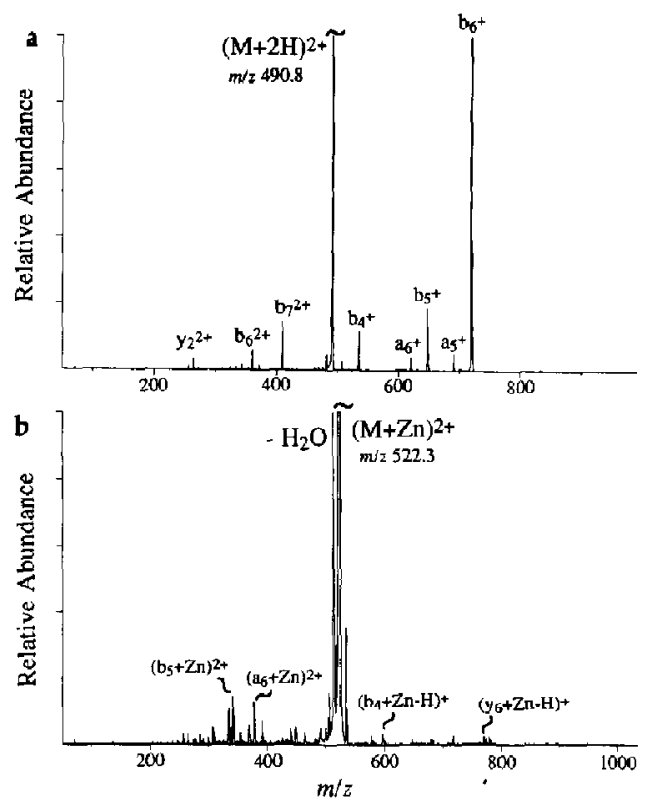

Figure 6. ESI-CAD (B/E linked scan) mass spectra of the (a) $[\mathrm{M}+2 \mathrm{H}]^{2+}$ and (b) $[\mathrm{M}+\mathrm{Zn}]^{2+}$ molecules of the non-histidine-containing peptide DRVYIAPF $\left(\mathrm{M}_{\mathrm{r}}=979.5\right)$.

ions under CAD conditions [39], but Loo et al. [39] have provided evidence from low energy CAD experiments that the process may not be as favorable when $X$ is a positively charged basic residue (i.e., Arg, Lys, His). It is unlikely that proline plays a major role in the formation of the $\left[b_{6}+\mathrm{Zn}\right]^{2+}$ product ion for zinc-containing angiotensin peptides. The CAD spectrum for $\left(\left[\mathrm{Ala}^{7}\right] \text { - angiotensin II }+\mathrm{Zn}\right)^{2+}$ (where Pro ${ }^{7}$ has been replaced by alanine) is virtually the same as the [angiotensin $\mathrm{II}+\mathrm{Zn}]^{2+}$ complex (see Figures $2 \mathrm{~b}$ and $3 b$ ); the $\left[b_{6}+\mathrm{Zn}\right]^{2+}$ product is the dominant fragment species.

The only other significant CAD fragmentation of $\mathrm{Zn}^{2+}$-angiotensin peptide complexes is the loss of water. The relative abundance of the water loss product is about $30 \%$ for the angiotensin II-zinc complex, whereas the ion due to water loss is the most abundant fragment for the angiotensin I and $\left[\mathrm{Ala}^{6}\right]$-angiotensin II complexes. The $\mathrm{N}$-terminal aspartic acid is apparently the site for water loss to occur because no water loss was observed from zinc-peptide complexes that do not contain aspartic acid (e.g., substance P). The C-terminal site is eliminated as a possible zinc binding site because the CAD spectrum of [AAAYAA $+\mathrm{Zn}]^{2+}$ showed no significantly abundant $\left[\mathrm{M}-\mathrm{H}_{2} \mathrm{O}+\mathrm{Zn}\right]^{2+}$ ion. $C A D$ of the $[\mathrm{M}+2 \mathrm{H}]^{2+}$ angiotensin peptide molecule did not yield a product from the loss of water; thus the reaction of elimination of a water molecule appears to be promoted by metal binding. This leads to the possibility of metal binding to the $\mathrm{N}$-terminal residue. Supporting evidence is provided from the observed enhancement of the formation of the 
$\left[\mathrm{M}-\mathrm{H}_{2} \mathrm{O}+\mathrm{Zn}\right]^{2+}$ ion (Figure 6) from the $[\mathrm{M}+$ $\mathrm{Zn}]^{2+}$ complex of [Ala $\left.{ }^{6}\right]$-angiotensin II compared with the zinc-angiotensin II complex (Figures $2 b$ and $3 b$ ). The replacement of histidine by alanine at position 6 of angiotensin II eliminated the "preferred" $\mathrm{Zn}^{2+}$-binding site, and the N-terminal residue becomes the most favored $\mathrm{Zn}^{2+}$ site. The apparent increase in metal binding to the $\mathrm{N}$-terminus results in a more abundant water loss ion in the CAD spectrum. However, the loss of water is also the most facile process in the CAD of the $\mathrm{Zn}^{2+}$ complex of $\mathrm{N}$-acetyl-renin substrate tetradecapeptide (Ac-DKVYIHPFHLVIHN), Because the $N$ terminus is no longer a primary amino group, the abundant water loss only suggests that aspartic acid itself is a favorable $\mathrm{Zn}^{2+}$ binding site. Therefore, the $\mathrm{N}$-terminal $7 \mathrm{n}^{2+}$ binding revealed by our CAD data could be a result of the intrinsic affinity of $\mathrm{Zn}^{2+}$ toward the aspartic acid residue, which also was reported to be a good $\mathrm{Zn}^{2+}$ ligand [34]. The question regarding the intrinsic affinity of aspartic acid is beyond the scope of this paper and is to be addressed in a later study. Thus, the N-terminus also appears to participate in zinc binding, contributing to the structure composite of $\mathrm{Zn}^{2+}$-angiotensin peptide complexes, although the population of the complexes that have such metal binding appears to be small.

To explain the tandem mass spectrometry experimental observations, a structure that presents strong metal binding and at the same time facilitates the fragmentation pathways in the CAD is necessary. Histidine is the most frequently found metal-binding ligand in $\mathrm{Zn}^{2+}$ sites of enzymes [34]. It coordinates to metal ions by its imidazole ring nitrogen(s). In the postulated structure $1, \mathrm{Zn}^{2+}$ is coordinated to one of the imidazole nitrogens and two immediate carbonyl oxygens. The metal binding in this structure imparts minimum constraints on the peptide. Only histidine and the preceding carbonyl group are subjected to constraints. From an entropy loss point of view this structure has obvious advantages over metal binding to other amino acids or to the N-terminal amine group because a tridentate metal binding requires folding a much larger portion of the peptide. Formation of $b$-type ions at the histidine site from this structure is feasible and the charge on the immediately neighboring metal ion should be effective in activating the bonds.

Bidentate coordination of $\mathrm{Zn}^{2+}$ by the two histidine residues of angiotensin $I$ is also possible, as suggested

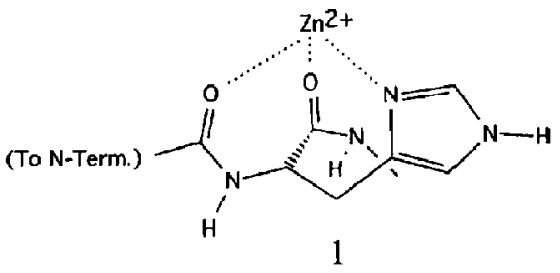

Structure 1 by NMR studies [41]. The weakly formed $a_{6}^{2+} / b_{6}^{2+}$ pair (compared with $a_{9}^{2+} / b_{9}^{2+}$ ) from the angiotensin I $[\mathrm{M}+\mathrm{Zn}]^{2+}$ complex may point to bidentate coordination because such a structure should promote the formation of $a_{9}^{2+} / b_{9}^{2+}$ and inhibit the formation of the $a_{6}^{2}+/ b_{6}^{2}$ product ion pair. The weak formation of $a_{6}^{2+} / b_{6}^{2+}$ may be the result of a composite of structures (i.e., some fraction of the population of the complex may have a monodentate structure). Further evidence also can be found in the ESI mass spectra (Figure 1). The relative ratio of the ions that have two zinc metal ions attached to the peptide $\left([\mathrm{M}+2 \mathrm{Zn}]^{4+}\right)$ to the ions with one zinc attachment $\left([\mathrm{M}+\mathrm{Zn}]^{2+}\right)$ are similar for angiotensin $I$ and angiotensin $I$. The additional histidine residue in angiotensin I does not increase the relative abundance of the ions that contain two zinc ions. Apparently, the two histidine residues in angiotensin I do not harbor metal ions separately.

Metal ions such as $\mathrm{Ni}^{2+}$ and $\mathrm{Cu}^{2+}$ have been shown to bind to human angiotensin II (DRVYIHPF) in the vicinity of the imidazole nitrogen of the histidine side chain $[42,43]$. A recent ${ }^{1} \mathrm{H}$ NMR study provided evidence for $\mathrm{Zn}^{2+}$ coordination to the imidazole rings of both histidine residues of human angiotensin I [41]. The binding sites of copper and palladium to angiotensin $\mathrm{I}$ and II were also assessed by using californium-252 plasma desorption ( $\left.{ }^{252} \mathrm{CF}-\mathrm{PD}\right)$ mass spectrometry $[44,45]$. From the fragment ions observed in the PD mass spectra of peptide samples that contain metal ions, it was concluded that the $\mathrm{NH}_{2}$-terminal amino group as well as the histidine imidazole ring are the metal-binding sites; the $\mathrm{NH}_{2}$-terminal amino group has a stronger affinity for $\mathrm{Cu}$ (II) and $\mathrm{Pd}(\mathrm{II})[44,45]$. Our ESI tandem mass spectrometry data support the histidine site as the most favored region for zinc binding. ESI tandem mass spectrometry experiments with copper and palladium will be needed to clarify the discrepancies in the data from the two methods. Tandem mass spectrometry is more likely a less ambiguous method for distinguishing between specific and nonspecific interactions.

\section{Conclusions}

Electrospray ionization combined with tandem mass spectrometry has allowed the study of interactions between neutral peptides (no deprotonation of an amide group) and metal ions. Interactions of this nature in the gas phase are usually not amenable to investigations by other mass spectrometry ionization techniques (e.g., fast-atom bombardment). The dissociation of these gas-phase complexes occurs nearly exclusively at the histidine site(s), which suggests that $\mathrm{Zn}^{2+}$ binds angiotensin peptides in the vicinity of the histidine residues in either a monodentate or bidentate structure. $\mathrm{Zn}^{2+}$ binding to the $\mathrm{N}$-terminus also may contribute to the structure composite, but the affinity of the $\mathrm{N}$-terminal amino group appears to be lower than the histidine residue. 


\section{Acknowledgments}

Partial support of this work was provided by the Director, Office of Health and Environmental Research, U.S. Department of Energy. Pacific Northwest Laboratory is operated by Battelle Memorial Institute for the U.S. Department of Energy under Research Contract No. DE-AC06-76RLO 1830. We thank Dr. Brenda Schwartz. and Dr. Ray Bakhtiar for helpful comments.

\section{References}

1. Glusker, J. P. In Advances in Protein Chemistry, Vol. 42; Anfinsen, C. B.; Edsall, J. T.; Eisenberg, D. S.; Richards, F. M. Ed.; Academic: San Diego, CA, 1991.

2. Riordan, J. F.; Vallee, B. L., Eds. Metallobiochemistry, Part C, Spectroscopic and Physical Methods for Probing Metal Ion Environments in Metalloenzymes and Metalloproteins, Vol. 226; Academic: San Diego, CA, 1993.

3. Riordan, J. F.; Vallee, B. L., Eds. Metallobiochemistry, Part D, Physical and Speciruscopic Melfidds for Probing Metal Lon Environments in Metalloproteins, Vol. 227; Academic: San Diego, CA, 1993.

4. Bertini, I.; Turano, P.; Villa, A. J. Chem. Rev. 1993, 93, 2833-2932.

5. Dent, A. J.; Beyersmann, C.; Block, C.; Hasnain, S. S. Biochemistry 1990, 29, 7822-7828.

6. Eggers-Borkenstein, P.; Priggemeyer, S.; Krebs, B.; Henkel, G.; Simonis, U.; Pettifer, R. F.; Nolting, H.-F.; Hermes, C. Eur. J. Biochem. 1989, 186, 667-675.

7. Hubbard, S. R.; Bishop, W. R.; Kirschmeier, P.; George, S. J.; Cramer, S. P.; Henrickson, W. A. Science 1991, 254, 1776-1779.

8. Krebs, J. F.; Fierke, C. A. Biochemistry 1991, 30, 9154-9160.

9. Vallee, B. L.; Auld, D. S. Proc. Natl. Acad. Sci. USA 1990, 87, 220-224.

10. Mallis, L. M.; Russell, D. H. Anal. Chem. 1986, 58, 1076-1080.

11. Russell, D. H.; McGlohon, E. S.; Mallis, L. M. Anal. Chem. $1988,60,18181824$.

12. Kulik, W.; Heerma, W.; Terlouw, J. K. Rapid Commun. Mass Spectrom. 1989, 3, 276-278.

13. Tomer, K. B.; Deterding, L. J.; Guenat, C. Biol. Mass Spectrom. 1991, 20, 121-129.

14. Grese, R. P.; Cerny, R. L.; Gross, M. L. I. Am Chem. Soc. 1989, $171,2835-2842$.

15. Teesch, L. M.; Adams, J. J. Am. Chem. Soc. 1991, 113, 812-820.

16. Teesch, L. M.; Orlando, R. C.; Adams, J. f. Am. Chem. Soc. 1991, 113, 3668-3675.

17. Tang, X.-J.; Thibault, P.; Boyd, R. K. Org. Mass Spectrom. 1993, $28,1047-1052$.

18. Hu, P. F.; Gross, M. L. J. Am. Chem. Soc. 1992, 114, 9153-9160.

19. Hu, P. F.; Gross, M. L. I. Am. Chem. Soc 1992, 114, 9161-9169.

20. Teesch, L. M.; Adams, J. J. Am. Chem. Soc. 1990, 112, 4110- 4120 .
21. Zhao, H.; Reiter, A.; Teesch, L. M.; Adams, J. J. Am. Chem. Soc. 1993, 115, 2854-2863.

22. Hu, P. F.; Gross, M. L. J. Am. Chem. Soc. 1993, 115, 8821-8828.

23. Meng, C. K.; Mann, Mi; Fenn, J. B. Z. Phys. D 1988, 10, 361-368.

24. Smith, R. D.; Lon, J. A.; Ogorzalek Loo, R. R.; Busman, M.; Udseth, H. R. Mass Spectrom. Rev. 1991, 10, 359-451.

25. Loo, J. A.; Edmonds, C. G.; Smith, R. D. Science 1990, 248, 201-204.

26. Hutchens, T. W; Allen, M. H. Rapid Commun. Mass Spectrom. 1992, 6, 469-473.

27. Allen, M. H.; Hutchens, T. W. Rapid Commun. Mass Spectrom. 1992, 6, 308-312.

28. Hutchens, T. W.; Nelson, R. W.; Allen, M. H.; Li, C. M.; Yip T. T. Biol. Mass Spectrom. 1992, 21, 151-159.

29. Yu, X. L.; Wojcicchowski, M.; Fensclou, D. Anal. Chem. 65, $1355-1359$.

30. Hu, P. F.; Gross, M. L. J. Am. Soc. Mass Spectrom, 1994, 5, 137-143.

31. Sigel, H.; Martin, R. M. Chem. Rev. 1982, 82, 385-426.

32. Cunnane, S. C. Zinc: Clinical and Biochemical Significance; CRC Press: Boca Raton, FL, 1988.

33. Christianson, D. W. In Advances in Protein Chemistry; Anfinsen, C. B.; Edsall, J. T.; Eisenberg D. S.; Richards, F. M. Eds.; Academic: San Diego, CA, 1991; pp 281-355.

34. Vallee, B. L.; Auld, D. S. Acc. Chem. Res. 1993, 26, 543-551.

35. Smith, R. D.; Loo, J. A.; Barinaga, C. J-; Edmonds, C. G.; Udseth, H. R. J. Am. Soc. Mass Spectrom. 1990, 1, 53-65.

36. Ikonomou, M. G.; Blades, A. T.; Kebarle, P. J. Am. Soc. Mass Spectrom. 1991, 2, 492-496.

37. Loo, J. A.; Giordani, A. G.; Muenster, H. Rapid. Commun. Mass Spectrom. 1993, 7, 186-189.

38. Biemann, K. Biomed. Environ. Mass Spectrom. 1988, 16, 99-111.

39. Loo, J. A.; Edmonds, C. G.; Smith, R. D. Anal. Chem. 1993, 28 , 1640-1649.

40. Loo, J. A.; Ogorzalek Loo, R. R.; Andrews, P. C. Org. Mass Spectrom. 1993, 28, 1640-1649.

41. Arnold, A. P.; Stanley, D. M.; Collins, J. G. FEBS Lett. 1991, $289,96-98$.

42. Decock-Le Reverend, B.; Liman, F.; Livera, C.; Pettit, L. D.; Pyburn, S.; Kozlowski, H. I. Chem. Soc. Dalton Trans. 1988, 887-894.

43. Pettit, L. D.; Pyburn, S.; Kozlowski, H.; Decock-LeReverend, B.; Liman, F. I. Chem. Soc. Dalton Trans. 1989, 1741-1475.

44. Hu, Z; Macfarlane, R. D. In 39th ASMS Conference on Mass Spectrometry and Allied Topics; Nashville, TN, 1991; pp $481-482$.

45. Hu, Z; Macfarlane, R. D. In 40th ASMS Conference on Mass Spectrometry and Allied Topics; Washington, DC, 1992; pp $580-581$. 